\title{
e-Phaïstos
}

e-Phaïstos

Revue d'histoire des techniques / Journal of the history

of technology

IV-1 | 2015

Les arts de guerre et de grâce (XIVe-XVIIIe siècles)

\section{L'utilisation du bois de cerf au Moyen-Âge : un matériau, des techniques}

The utilization of deer antlers in the Middle Ages: one material, multiple techniques

Jean-François Goret

\section{OpenEdition}

Journals

Édition électronique

URL : http://journals.openedition.org/ephaistos/830

DOI : 10.4000/ephaistos.830

ISSN : 2552-0741

Éditeur

IHMC - Institut d'histoire moderne et contemporaine (UMR 8066)

Édition imprimée

Date de publication : 1 avril 2015

Pagination : 74-82

ISSN : $2262-7340$

Référence électronique

Jean-François Goret, «L'utilisation du bois de cerf au Moyen-Âge : un matériau, des techniques », e-

Phaïstos [En ligne], IV-1 | 2015, mis en ligne le 22 novembre 2016, consulté le 19 avril 2019. URL

http://journals.openedition.org/ephaistos/830 ; DOI : 10.4000/ephaistos.830

Ce document a été généré automatiquement le 19 avril 2019

Tous droits réservés 


\section{L'utilisation du bois de cerf au Moyen-Âge : un matériau, des techniques}

The utilization of deer antlers in the Middle Ages: one material, multiple techniques

Jean-François Goret

\section{NOTE DE L'ÉDITEUR}

Nous n'avons pas obtenu l'autorisation de publier cet article en ligne.

\section{RÉSUMÉS}

Le mobilier en bois de cerf découvert sur les sites médiévaux révèle la parfaite maîtrise des propriétés et contraintes du matériau acquises par les artisans. L'analyse des objets permet de distinguer deux approches dans l'exploitation de cette ressource. Par ailleurs, elle met en évidence le caractère précieux d'une partie située à la base des bois, le pédicule ou pivot, dont les propriétés se rapprochent de celle de l'ivoire.

Deer antler artifacts found at medieval sites reveal a total mastery of the properties and constraints of this material on the part of the artisans. The study of these objects allows one to distinguish two approaches to the utilization of this resource. Furthermore, it highlights the 
valuable nature of a part of the antler situated at the base or pedicle, whose properties are similar to those of ivory.

INDEX

Mots-clés : histoire des techniques, Moyen-Âge, Europe, bois de cerf, jeu d'échecs

Thèmes : Un objet une technique

\section{AUTEUR}

JEAN-FRANÇOIS GORET

Archéologue, département d'Histoire de l'Architecture et d'Archéologie de Paris 